\title{
Development and Integration of an Instructional Garden in Education at the University of Wisconsin-Madison
}

\author{
Dennis P. Stimart
}

\begin{abstract}
Additional INDEX Words. teaching, instruction, Allen Centennial $\mathbf{G}$ ardens
Summary. The Allen Centennial $G$ ardens are instructional gardens managed by the D epartment of $H$ orticulture, $U$ niversity of Wisconsin-M adison. Twenty-two garden styles exist on the 2.5-acre (1.0-ha) campus site with a primary focus on herbaceous annual, biennial and perennial ornamental plants. The gardens are used for instruction mostly by the Department of $\mathrm{H}$ orticulture and secondly by departments of art, botany, entomology, landscape architecture, plant pathology, and soils. Class work sessions are limited due to the gardens' prominence on campus, high aesthetic standards, space restrictions, and large class sizes. U ndergraduate students are the primary source of labor for plant propagation, installation and maintenance; management; and preparation of interpretive literature. Work experience at the gardens assists students with obtaining career advances in ornamental horticulture. Future challenges include initiating greater faculty use of the gardens for instruction and creating innovative ways to use the gardens to enhance instruction.
\end{abstract}

$\mathrm{T}$ he Allen Centennial Gardens (ACG) are horticultural gardens managed by the $U$ niversity of $W$ isconsin-M adison, D epartment of $\mathrm{H}$ orticulture. The mission of the gardens is to provide an outdoor instructional and laboratory facility for a broad range of disciplines including horticulture, landscape architecture, and related areas of interest. A continuing goal of the gardens is to provide state of the art demonstrations and information on use of traditional and novel plants in diverse landscape settings. To accomplish this, the gardens constantly evolve to reflect the most recent innovations in horticulture and landscaping. An important function of the gardens is to provide an extension and outreach instructional facilities. Clientele include university and college students, $\mathrm{K}$ through 12 students, garden clubs, master gardeners, the landscape and horticultural industries, and other groups and individuals with an interest in landscaping and horticulture. The primary client of the gardens is a university student enrolled in course work related to the garden's mission. A secondary mission of the gardens is to provide a pleasant horticultural setting for enjoyment by the public.

\footnotetext{
D epartment of H orticulture, U niversity of Wisconsin, 1575 Linden D rive, M adison, WI 53706.

U se of trade names does not imply endorsement of the products named or criticism of similar ones not named. The cost of publishing this paper was defrayed in part by the payment of page charges. U nder postal regulation, this paper therefore must be hereby-marked advertisement solely to indicate this fact.

${ }^{1}$ Professor, director, Allen Centennial Gardens.
} 


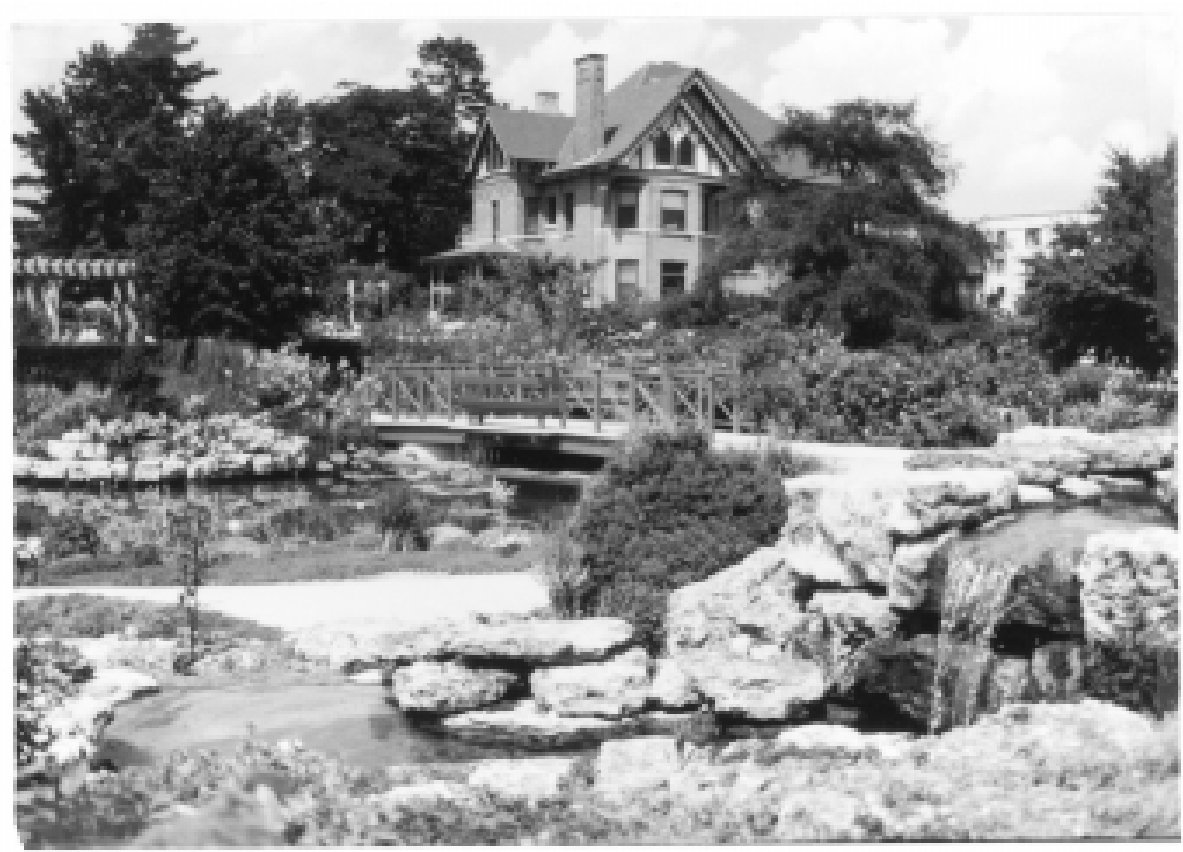

Fig. 1A. The Allen C entennial $G$ ardens at the $U$ niversity of $W$ isconsin-M adison campus: historic Victorian G othic residence. of Wisconsin-M adison campus sur- styles ranging from traditional to contemporary: Gardens Alpine, Annual Shady, Annual Sunny, D warf Conifer, English, French (Fig. 1B), H erb, $\mathrm{H}$ illsideShrub, I ris(Fig. 1C), I talian, N ew American (Fig. 1D), Small Fruit, T ree Fruit, Tapestry des Flore, Turf, Vegetable Annual, Vegetable Perennial, Victorian, Vine (Fig. 1E), Water, Wetland (Fig. 1F), and Woodland. Primary emphasis is on herbaceous ornamental annual, biennial and perennial plants with about one-tenth space devoted to woody plants. Additionally, $\approx 60$ containers feature ornamentals, fruits, and vegetables cultured in various media (Fig. 1G).

The gardens are open daily during daylight hours free of charge to providemaximum accessibility. T ables, chairs and benches are located strategically throughout the gardensto provide privacy, view and accommodate users.

\section{Student involvement} gardens are located on the $U$ niversity rounding a historic Victorian Gothic residence ( $F$ ig. 1A) formerly used by the deans of the College of Agricultural and Life Sciences. The 2.5-acre (1.0 ha) site is composed of 22 garden

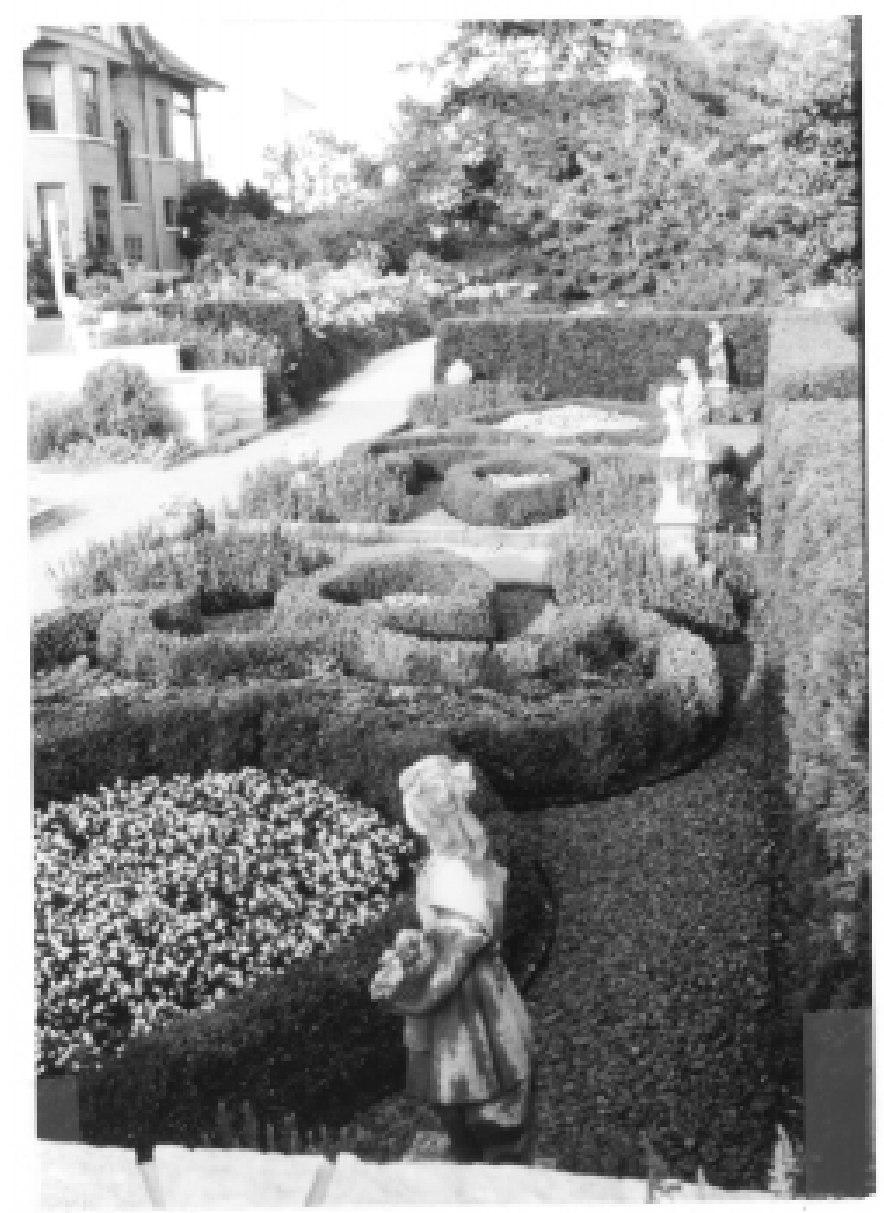

IMPLEMENTATION. The master plan and planting plans for the gardens were prepared from 1987 to 1989 by a hired landscape architectural firm in Wisconsin. Studentshired by the landscape architect as summer interns assisted in design of walkways and walls, and plant selection. To assist in master plan evaluation, an advisory committee was established consisting of thirteen members: four Department of $\mathrm{H}$ orticulture faculty, three private sector landscape architects, three state landscapearchitects, two campus physical plant personnel, and one garden staff member. M eetings were held monthly over 14 months to evaluate phases of master plan and planting plan development. The diversity and expertise of this committee was effective with integrating the garden's mission, campus safety and aesthetics into the master plan. Garden implementation was from 1987 to 1994 in increments based on achieving underwriting goals. Trade professionals constructed major hardscapeitemssuch as a service building, gazebo, pavilion, pergola, bridge, brick and concrete walkways, stone walls, a wetland garden, a water garden, and utilities of electric and plumbing. U se of trade

Fig. 1B. The Allen Centennial $G$ ardens at the $U$ niversity of $W$ isconsin-M adison campus: $F$ rench $G$ arden. 
professionals expedited implementation and provided quality workmanship. I nexperience, complex state guidelines and pressing completion dates excluded student involvement in hardscape construction. V olunteer and hired undergraduateand graduatestudents provided planting plan layout, and plant installation. Students in- volved brought enthusiasm and energy to accomplishing tasks. Thegreatest challenge with student assistance was mobilizing critical numbers of workers for periods of time long enough to complete tasks.

UNDERWRITING. U nderwriting for construction and endowment of the gardens started in 1980 with the U ni-

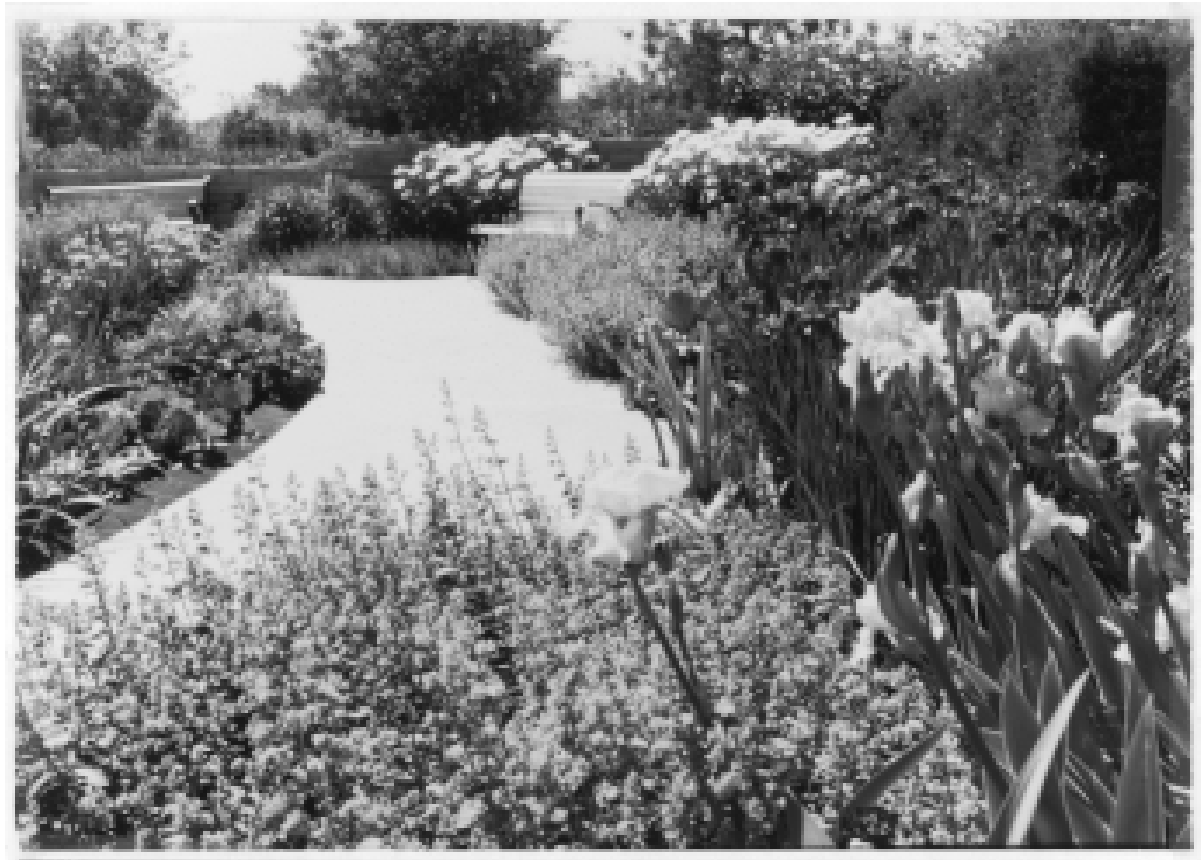

Fig. 1C. The Allen Centennial $G$ ardens at the $U$ niversity of WisconsinMadison campus: I ris $\mathrm{G}$ arden.

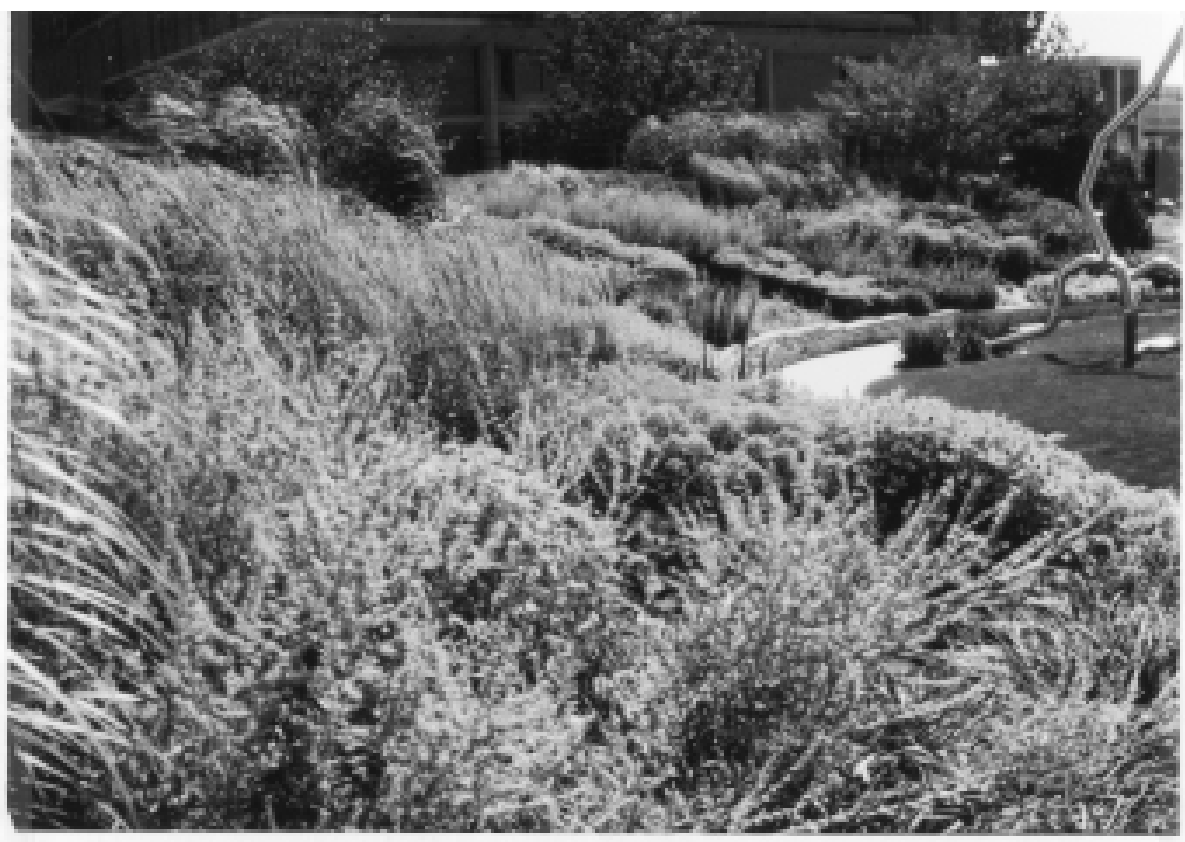

Fig. 1D. The Allen C entennial $G$ ardens at the University of WisconsinMadison campus: $\mathbf{N}$ ew American $\mathbf{G}$ arden. versity of Wisconsin Foundation and the garden director. T otal project cost was $\$ 2.5$ million: $\$ 1.0$ million for construction and $\$ 1.5$ million for endowment. Professional underwriting was necessary to identify major donors, initiate donor-recipient relationships and manage the diversity of gift forms received.

The use of students individually or in groups for underwriting was difficult to accomplish from inexperience, busy schedules and short term availability to develop an extended working relationship with potential underwriters. O pportunity existed for student organizations to financially assist the gardens; however, the fluid nature and constantly changing landscape of these organizations resulted in variable support. With the right mix of students, underwriting for ACG was achieved: about $\$ 10$ thousand over 15 years. Student organizations raised money simultaneously for themselves and the gardens from sales of traditional cut flowers and potted plants sold around holidays, finished indoor foliage plants sold at start of fall semester, and finished and student grown bedding plantssold in thespring. Plant sales were held on campus in tents or buildings over 3 to $4 \mathrm{~d}$. Students handled and gained experiencein plant sourcing, purchase, transport, and maintenance; propagation; crop forcing; marketing; and staff management. Also, they answered questions on culture and distributed written information on individual plant care. Thegreatest contribution from students to underwriting wasindirect, by having students in the gardens working or taking courses when prospective and existing underwriters visited.

INTERPRETIVE MATERIALS. M aps and plant identification information exist at an orientation site located near the gardens entrance to assist students and visitors in learning. Brochures are available on component gardens as a onepage trifold consisting of description of garden style and history; a planting plan with location of each herbaceous and woody plant; genus, species, cultivar, and common names; and key references. Brochure format allows for selfguided discovery and tour, and preliminary information for further learning. About 2500 copies of each brochureare provided free to visitors annually.

Students are asked to work with the garden director to prepare bro- 


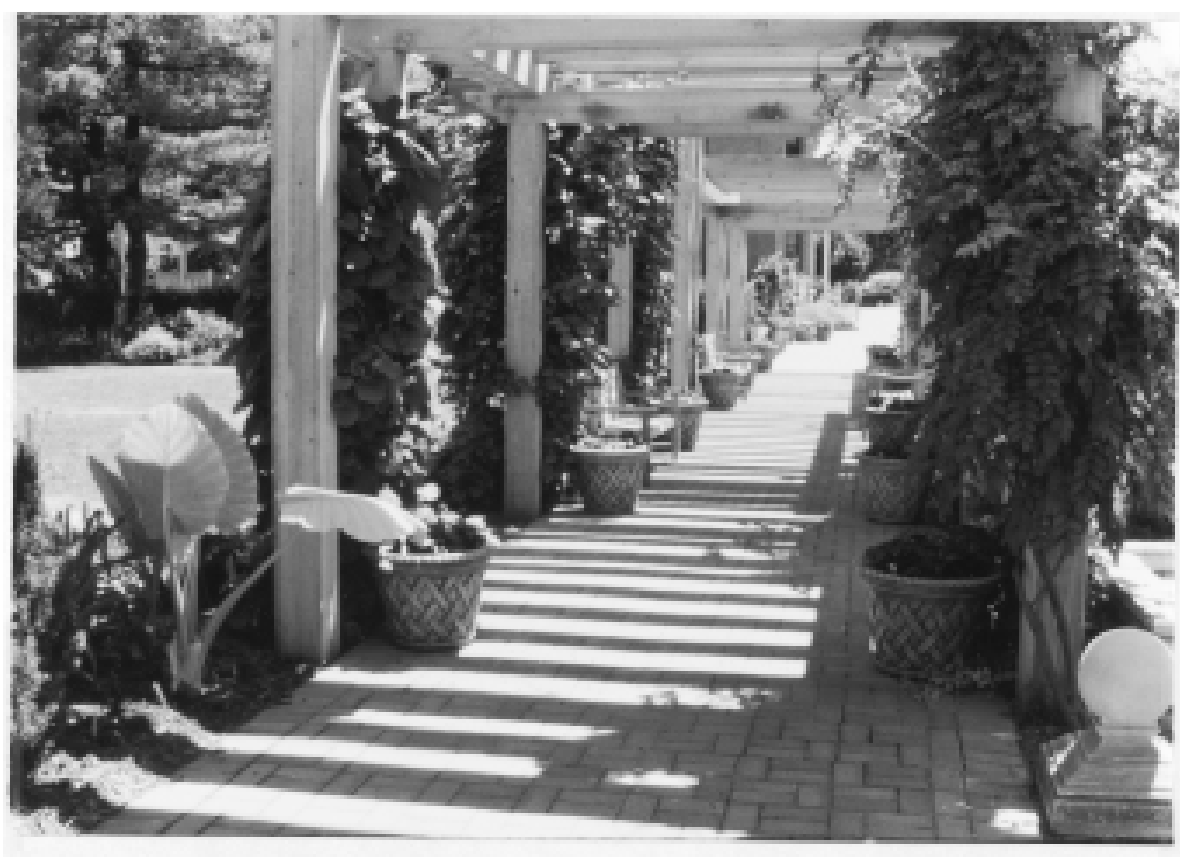

Fig. 1E. The Allen Centennial $G$ ardens at the $U$ niversity of Wisconsin-Madison campus: Vine $\mathbf{G}$ arden.

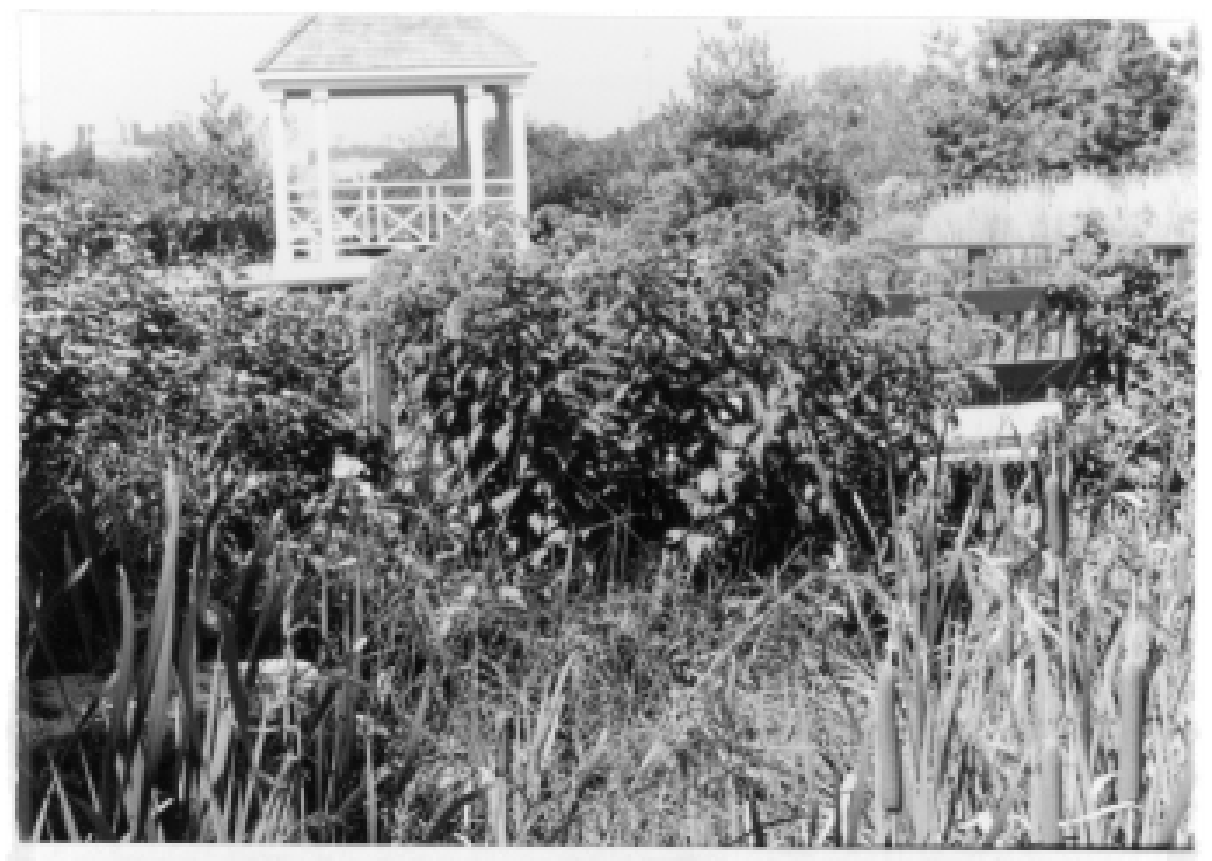

Fig. 1F. The Allen C entennial $G$ ardens at the $U$ niversity of $W$ isconsin-M adison campus: Wetland Garden.

chures if they have expertise in a garden style, specific plant materialsand writing skills. Campus computers and software programs are used to develop text and art. Students may register for 1 or 2 credits of special problems in completing the task and are recognized on the brochure for contributions.

Tours. The garden director, head gardener, faculty, or students give free guided tours consisting of history of the site, definition of gardens, plant identification and culture. Student employees provide tours once they learn relevant information and develop group presentation skills. L ess experienced employees are encouraged to develop skills by meeting visitors and answering questions.

Public use. U niversity functions, private parties, weddings, etc. are held in three areas of the gardens for a fee. Site capacity ranges from 40 to 250 people. Student employees assist functions by site preparation, event monitoring, clean up, and tending vendors. E vents can last 2 to $4 \mathrm{~h}$ with 1 to $2 \mathrm{~h}$ additional time needed to attend tasks before or after event activities. M ost events are held during nontraditional working hours on evenings, weekends and holidays, and monitored equally by garden employees. R esponsibilities include working knowledge of garden and campusoperations, providing services to users, and protecting garden integrity. D uring events, garden employees work on low-level tasks out of sight.

Plant labeling. A plant labeling system exists to track and identify inventory. Labels consist of an accession number incorporating year and plant identification; genus; species; cultivar; and common name. Information is maintained on a departmental database under the garden director. Plant labels are formulated from the database by word processor, printed by laser jet on clear laminating sheets, sealed in plastic pouches, and placed on metal stakes adjacent to respective plants. Labeling format parallels identification information on brochures discussed previously. Student employees knowing plant materials, nomenclature, and capable of detailed work do field inventory, data entry, and label preparation and installation. Students learn plant materials, accession management, nomenclature, and communication skills.

INSTRUCTION. The D epartment of $\mathrm{H}$ orticulture is the primary user of the gardens for undergraduate courses of introductory horticulture, herbaceous and woody ornamental plant materials, vegetables, fruits, and turf. Secondary users include departments of art, entomology, landscape architecture, plant pathology, and soil science. $U$ se varies from frequent for plant material courses to intermittent for art courses.

Prominence of the gardens in a visible campus location is beneficial but creates instructional challenges. The high aesthetic standards expected of the gardens and limited open space to work restricts class activities. Concepts are presented primarily via class demonstration by the instructor and compared to results of the exercise per- 


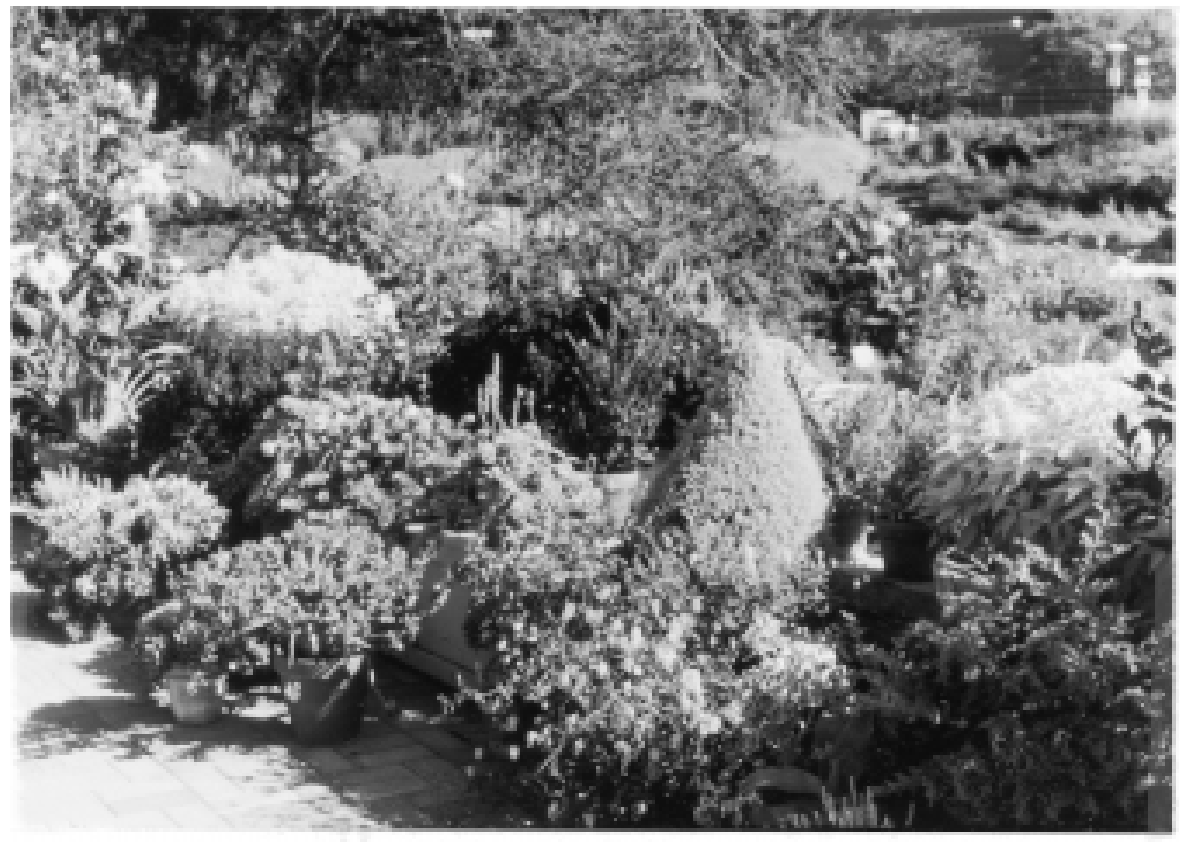

Fig. 1G. The Allen C entennial $\mathbf{G}$ ardens at the $\mathbf{U}$ niversity of Wisconsin-M adison campus: $C$ ontainer Garden.

formed previously. Students desiring work experience are encouraged to seek employment or volunteer at the gardens.

Thegardensarearesourceof living insects, diseases and plant parts for indoor and outdoor instructional use by professors, teaching assistants and undergraduate students. Collecting at the gardens is allowed with permission for instructional purposes. Students needing to make individual collections of plants, insects, etc. for class projects are encouraged to use the gardens as the source of specimens. Student employees assist with locating and collecting items sought by instructors.

LABOR. A head gardener worksfulltime at the gardens overseeing daily activities and supervising six student positions: two for advanced students as an intern and a crew manager, and four with limited experience. The student intern is an experienced upper class student hired part-time during spring and fall semesters, and full-time in summer as a onetime hire. Primary assignment is the rock garden with secondary commitment to other garden areas. Two experienced rock gardeners supervise the intern to learn plant materials, culture, maintenance, and labeling. Additionally, the intern does independent study for credit on a topic mutually agreed upon by the garden director and theintern, and of benefit to thegardens. Previously, thishasincluded preparing a brochure for the rock gardens, plant inventory maintenance, developing a seasonal photo journal, building and establishing troughs, etc.

Crew manager is an upper class student invited to return for work fulltime during summer to work and manage activities of new crew hires. This person supervises field activities and monitorswork quality. The intern and crew managers have greatest management and decision making involvement, and earn the highest salaries.

The four positions for students with limited experience are available in summer with two full time and two part time, and in fall with four part time. First hire opportunity is granted to students with career interests in ornamental horticulture, landscape architecture, plant sciences, etc. and second choice is given to students majoring in other fields having previous work experience with ornamental plants.

Garden employees have a structured work pattern that includes assigned areas and group tasks in other areas. Each summer student isassigned a location to assess daily conditions and discuss tasks with the crew manager. Workdays begin at assigned areas for about $1 \mathrm{~h}$ and include watering, pruning, staking, weeding, etc. Then, students are assigned tasks more efficiently handled by groups such as mulching, planting, etc. Assignment to an area develops independence, a sense of ownership, pride, and accomplishment with a chance to observe seasonal changes in a cumulative and comprehensive manner. Group work develops skills in working together. This pattern of labor management allows employees to foster critical thinking, decision making, and management.

Student volunteers work in the gardens for pleasure, interest, or to gain experience in order to qualify for work at ACG or another public garden. The department'sundergraduate $\mathrm{H}$ orticulture Society holds work sessions occasionally for a few hours to completetasks of pressing urgency like mulching, planting containers, etc.

Local high schools training students in ornamental horticulture hold work sessions occasionally at the gardensfor several hours oncea week over several weeks. Students interested in continuing their work experience may apply for one-half time summer hire.

Student work experience at ACG is intended to be a career primer for entrance to more advanced training elsewhere. Former student workers have emphasized the value of their working experience at ACG for entrance to internships at other gardens or arboreta in the U nited States or abroad, graduate study, landscape architecture programs, or the ornamental horticulture industry.

\section{Conclusion}

Benefits and challenges have resulted from development of an instructional garden on the campus of a major research university. The benefit is in supporting the instructional mission of departments in the College of Agricultural and Life Sciences, and departments in other colleges. Also, it is a powerful public relations vehicle for the U niversity of $W$ isconsin-M adison and local community. The greatest challenge is getting more instructional use of the facility and encouraging faculty to be more creative in ways to meld the gardens into instruction. $\mathrm{M}$ any faculty on campus have a provincial view of gardens and are challenged with ways to integrate an instructional garden into relevance in the classroom. This provides an opportunity and an unexplored frontier. $\mathrm{N}$ ovel ways to integrate the gardens into affective instruction aretheagenda of current work. 